\title{
Pendataan dan Penyaluran Bantuan Langsung Tunai Dana Desa Penanggulangan Covid 19 oleh Pemerintah Desa Di Kecamatan Depati VII Kabupaten Kerinci
}

\author{
M. Muslih', Herma Yanti ${ }^{2}$ \\ ${ }^{1,2}$ Fakultas Hukum Universitas Batanghari Jalan Slamet Riyadi Broni Kota Jambi, Telp: (0741) 65351 \\ *Correspondence email : muslih.ubr@gmail.com; hermayanti67@gmail.com
}

\begin{abstract}
Abstrak. Pendataan dan penyaluran Dana Bantuan Langsung Tunai (BLT) Dana Desa oleh Kepala Desa merupakan pelaksanaan program Pemerintah Pusat dalam rangka membantu meringankan beban ekonomi masyarakat miskin yang terdampak akibat wabah Covid-19. Kegiatan pendataan dan penyaluran Dana Desa tersebut dilaksanakan melalui Kepala Desa masing-masing agar bantuan tersebut dapat disalurkan dengan lancar dan tepat sasaran sesuai tujuan yang telah ditetapkan, termasuk di Wilayah Kecamatan Depati VII Kabupaten Kerinci. Namun dalam implementasinya, kegiatan pendataan dan penyaluran menjadi sorotan karena ditemui adanya ketidaksesuaian dengan tujuan yang diharapkan. Karena itu penelitian ini bertujuan untuk membahas lebih lanjut pelaksanaan pendataan dan penyaluran Dana BLT Dana Desa di Kecamatan Depati VII Kabupaen Kerinci serta masalahmasalah yang ditemui di dalamnya.
\end{abstract}

Kata kunci : Pendataan dan penyaluran, Dana BLT Covid-19, Desa Kecamatan Depati VII Kerinci

\begin{abstract}
The data collection and distribution of the Village Fund Direct Cash Assistance (BLT) by the Village Head is the implementation of the Central Government program in order to help ease the economic burden of the poor who are affected by the Covid-19 outbreak. The data collection and distribution of Village Funds is carried out through the respective Village Heads so that the assistance can be distributed smoothly and on target according to the goals that have been set, including in the District of Depati VII, Kerinci Regency. However, in its implementation, data collection and distribution activities are in the spotlight because there are discrepancies with the expected goals. Therefore, this study aims to further discuss the implementation of data collection and distribution of the Village Fund BLT Fund in the District of Depati VII, Kerinci Regency and the problems encountered in it.
\end{abstract}

Keywords: Data collection and distribution, Covid-19 BLT Fund, Village District Depati VII Kerinci.

\section{PENDAHULUAN}

Terjadinya pandemi akibat merebaknya coronavirus disease 2019 (Covid 19), telah memporakporandakan sendi-sendi kehidupan masyarakat terutama di bidang perekonomian, karena hilangnya mata pencarian sebagian besar masyarakat yang sebelumnya menjadi andalan dalam menopang berbagai kebutuhan hidup dan keluarga. Hal ini memaksa pemerintah sebagai penanggung jawab atas berbagai kepentingan masyarakat untuk mencari mencari solusi dan jalan keluarnya. Dalam hal ini pemerintah telah berupaya membuat dan mengembangkan berbagai program untuk membantu meringankan beban serta keberlangsungan hidup masyarakat. Salah satunya melalui program Bantuan Langsung Tunai (BLT) Dana Desa yang diperuntukkan bagi masyarakat Desa.

Program BLT ini merupakan pengembangan dari program bantuan yang sudah ada sebelum mewabahnya Pandemic Covid-19 ini, seperti Program Keluarga Harapan (PKH) serta Kartu Prakerja. PKH diciptakan untuk mengurangi tingkat kemiskinan dengan memberikan bantuan untuk mengakses fasilitas kesehatan dan pendidikan yang diprioritaskan bagi keluarga yang kepala keluarganya adalah perempuan/lansia. Sedangkan Program Kartu Prakerja diciptakan untuk memberikan bantuan kepada warga masyarakat yang termasuk dalam golongan usia produktif dan belum memiliki pekerjaan atau kemampuan penyokong untuk mendapatkan pendapatan tetap untuk menyokong kehidupannya dan keluarga. Berbagai program-program bantuan yang sudah ada tersebut tentunya tidak relevan dengan timbulnya dampak yang lebih luas akibat terjadinya Pandemi Covid- 19 .

Sehubungan dengan itu pemerintah berupaya memperluas jangkauan bantuan-bantuan sosial yang harus disalurkan kepada masyarakat, khususnya untuk membantu masyarakat miskin serta membantu menstimulus kemampuan belanja dan perekonomian warga masyarakat yang kehilangan pekerjaan atau perekonomiannya terdampak oleh mewabahnya virus Covid-19. Sebuah program yang terstruktur dengan kriteria penerima yang benarbenar ditujukan untuk membantu warga masyarakat yang terdampak oleh wabah virus Covid-19 dan tidak tumpang tindih dengan Bantuan Sosial Lainnya.

Sesuai dengan Instruksi Presiden Nomor 4 Tahun 2020 tentang Recofusing Kegiatan, Relokasi Anggaran serta pengadaan barang dan Jasa dalam Rangka Percepatan Penanganan Corona Virus Disease 2019, Menteri Keuangan mengeluarkan PMK No 40 tahun 2020 tentang Perubahan Atas PMK 205/PMK.07/2019 Tentang Pengelolaan Dana Desa. Dalam ketentuan tersebut, BLT ini merupakan Bantuan Langsung Tunai Dana Desa (BLT-Dana Desa) berupa 
bantuan uang kepada keluarga miskin di Desa yang bersumber dari Dana Desa untuk mengurangi dampak Pandemi Covid-19 ${ }^{1}$. Program ini diperuntukkan untuk warga masyarakat kategori miskin yang terdampak langsung pendapatan perekonomiannya akibat wabah Virus Covid-19, termasuk masyarakat Desa di wilayah Kecamatan Depati VII Kabupaten Kerinci.

Sesuai ketentuan tersebut pemberian dana BLT Dana Desa tersebut dilakukan dengan melibatkan Pemerintah Desa yang diberikan tanggung jawab untuk melakukan kegiatan pendataan dan penyaluran Dana BLT Dana Desa Penanggulangan Covid kepada warga masyarakat Desa, begitu juga di Kecamatan Depati VII. Pemberian dana BLT Penanganan Covid-19 ini tidak hanya tentang jenis bantuan yang diberikan kepada masyarakat agar tidak tumpang tindih dengan penerima bantuan lainnya, namun juga harus melihat prosedur penyaluran dan pendataan yang berpedoman pada Peraturan Mentri Keungan Nomor 40 Tahun 2020 tentang Pengelolaan Dana Desa, Intruksi Mentri Dalam Negeri Nomor 3 Tahun 2020 tentang Penanggulangan Covid-19 di Desa melalui Anggaran Pendapatan dan Belanja Desa dan Peraturan Menteri Desa PDTT Nomor 6 Tahun 2020 tentang Prioritas Pengguna Dana Desa yang diantaranya terkait penyediaan Bantuan Langsung Tunai yang bersumber dari Dana Desa (BLT Covid-19 Dana Desa).

Pendataan dan penyaluran dana BLT Dana Desa ini diharapkan dapat dilakukan dengan cermat dan teliti. agar penyalurannya bantuan tersebut tepat sasaran dan sesuai dengan sasaran dan tujuan dibuatnya program BLT Dana Desa tersebut, yang pada dasarnya bertujuan untuk membantu menunjang kebutuhan pokok dan membantu menstimulus kemampuan belanja masyarakat desa-desa yang tidak mampu secara finansial. Di samping itu, mengingat banyaknya macam program bantuan sosial yang ada, maka perlu memperhitungkan bagaimana cara menghindari terjadinya tumpang tindih pemberian program bantuan sosial tersebut dengan bantuan yang lainnya. Namun dalam kenyataannya, pendataan dan penyaluran dalam pemberian bantuan BLT Dana Desa di Kecamatan Depati VII tersebut tidak berjalan sebagaimana mestinya, sehingga menimbulkan berbagai persoalan yang perlu dicarikan jalan keluarnya. Berdasarkan uraian tersebut, maka peneliti tertarik untuk melakukan penelitian lebih lanjut tentang pendataan dan penyaluran dana BLT Dana Desa Penanggulangan Covid 19 oleh Pemerintah Desa di Kecamatan Depati VII Kabupaten Kerici, serta permasalahan-permasalahan yang timbul dalam penyaluran Dana BLT Penanganan Covid 19 oleh Pemerintah Desa di Kecamatan Depati VII Kabupaten Kerici dan dan upaya penanggulangan yang dilakukan.

\section{Landasan Teori}

Penyelenggaraan tugas-tugas pemerintahan dalam menyelenggarakan berbagai kepentingan masyarakat harus mengacu pada rambu-rambu yang telah ditentukan guna mencegah terjadinya penyimpangan-penyimpangan dari tujuan yang hendak dicapai. Selain harus mengacu peraturan perundang-undangan, maka tindakan pemerintaahn juga harus mengacu pada Asas-asas umum pemerintahan yang Baik (AAUPB). AAUPB ini menjadi semakin penting, terutama dalam pelaksanaan tugas-tugas pemerintah yang dalam pelaksanaannya terdapat adanya keleluasaan yang dimiliki pemerintah dalam melakukan tindakan-tindakan yang diperlukan, sesuai dengan kondisi yang dihadapi.

Ridwan HR, menjelaskan bahwa AAUPB dapat dipahami sebagai asas-asas umum yang dijadikan sebagai dasar dan tata cara dalam penyelenggaraan pemerintahan yang layak, yang dengan cara demikian penyelenggaraan pemerintahan itu menjadi baik, adil dan terhormat, bebas dari kezaliman, pelanggaran peratuan, tindakan penyalahgunaan wewenang, dan tindakan sewenang-wenangnya. ${ }^{2}$

Lebih rinci Jazim Hamidi menjabarkan bahwa Asas-Asas Umum Pemerintahan Asas-Asas Umum Pemerintahan Yang Baik (AAUPB) tersebut sebagai berikut :

1. AAUPB merupakan nilai-nilai etik yang hidup dan berkembang dalam lingkungan hukum administrasi negara;

2. AAUPL berungsi sebagai pegangan bagi pejabat administrasi negara dalam menjalankan fungsinya, merupakan alat uji bagi hakim administrasi dalam menilai tindakan administrasi negara (yang berwujud penetapan/beschikking), dan sebagai dasar pengajuan gugatan bagi pihak pennggugat.

3. Sebagian besar dari AAUPB masih merupakan asas-asas yang tidak tertulis, masih abstrak, dan dapat digali dalam kehidupan dimasyarakat.

4. Sebagian asas yang lain sudah menjadi kaidah hukum tertulis dan terpencar dalam berbagai peraturan hukum positif. Meskipun sebagian dari asas itu berubah menjadi kaidah hukum tertulis, namun sifatnya tetap sebagai asas hukum. ${ }^{3}$

AAUPB dikatakan sebagai panduan jalannya hubungan pemerintah dan masyarakat. Oleh karena itu, AAUPB disebut sebagai rambu lalu lintas pemerintahan dan juga dasar untuk menilai bagi tiap tindak gerak pemerintah.

${ }^{1}$ KOMPAK (2020). Buku Saku Pendataan BLT Dana Desa [PDF], bappenas.go.id diakses 3 Agustus 2020

${ }^{2}$ Ridwan HR, Hukum Administrasi Negara, PT. Raja Grafindo, Jakarta, 2007, hal 247

${ }^{3}$ Jazim Hamidi, Penerapan Asas-Asas Umum Pemerintahan Yang Layak (AAUPL) di Lingkungan Peradilan Administrasi Indonesia, Citra Aditya Bakti, Bandung, 1999, hal 24 
Mengungat pentingnya AAUPB ini sebagai acuan dalam penyelenggaraan pemerintahan, keberadaannyapun di Indonesia kemudian telah dikukuhkan secara normative dalam beberapa peraturan perundang-undangan, mulai dari Undang-Undang Nomor 28 Tahun 1999 tentang Penyelenggara Negara Yang Bersih dan Bebas Korupsi, Kolusi dan Nepotisme, yang berlaku bagi semua penyelenggara negara. Kemudian khusus bagi penyelenggara pemerintahan, melalui Undang-UndangNomor 30 Tahun 2014 tentang Administrasi pemerintahan, Dalam Pasal 6 menegaskan bahwa Asas-Asas Umum Pemerintahan yang Baik (AUPB), sebagai salah satu asas dalam penyelenggaraan administrasi pemerintahan. Ditegaskan juga bahwa AUPB sebagai salah satu dasar wajib bagi Badan dan/atau Pejabat Pemerintahan dalam menggunakan wewenang, disamping berdasarkan pada peraturan perundang-undangan.

AUPB yang diatur dalam UU ini sebagaimana diatur dalam Pasal 10 yang terdiri dari :

1. asas kepastian hukum adalah asas yang mengutamakan landasan ketentuan peraturan perundang-undangan, kepatutan, keajegan, dan keadilan dalam setiap kebijakan penyelenggaraan pemerintahan.

2. asas kemanfaatan adalah manfaat yang harus diperhatikan secara seimbang antara berbagai kepentingan yang ada di dalamnya.

3. asas ketidakberpihakan, adalah asas yang mewajibkan Pejabat Pemerintahan dalam menetapkan dan/atau melakukan Keputusan dan/atau Tindakan dengan mempertimbangkan kepentingan para pihak secara keseluruhan dan tidak diskriminatif.

4. asas kecermatan, adalah bahwa suatu Keputusan dan/atau Tindakan harus didasarkan pada informasi dan dokumen yang lengkap untuk mendukung legalitas penetapan dan/atau pelaksanaan Keputusan dan/atau Tindakan sehingga Keputusan dan/atau Tindakan yang bersangkutan dipersiapkan dengan cermat sebelum Keputusandan/atau Tindakan tersebut ditetapkan dan/atau dilakukan.

5. asas tidak menyalahgunakan kewenangan adalah asas yang mewajibkan setiap Badan dan/atau Pejabat Pemerintahan tidak menggunakan kewenangannya untuk kepentingan pribadi atau kepentingan yang lain dan tidak sesuai dengan tujuan pemberian kewenangan tersebut, tidak melampaui, tidak menyalahgunakan, dan/atau tidak mencampuradukkan kewenangan.

6. asas keterbukaan, adalah asas yang melayani masyarakat untuk mendapatkan akses dan memperoleh informasi yang benar, jujur, dan tidak diskriminatif dalam penyelenggaraan pemerintahan dengan tetap memperhatikan perlindungan atas hak asasi pribadi, golongan, dan rahasia negara.

7. asas kepentingan umum, adalah asas yang mendahulukan kesejahteraan dan kemanfaatan umum dengan cara yang aspiratif, akomodatif, selektif, dan tidak diskriminatif.

8. asas pelayanan yang baik, adalah asas yang memberikan pelayanan yang tepat waktu, prosedur dan biaya yang jelas, sesuai dengan standar pelayanan, dan ketentuan peraturan perundang-undangan.

\section{METODE}

\section{Pendekatan Penelitian}

Sesuai dengan permasalahan yang dikemukakan, type penelitian ini adalah penelitian hukum empiris, yaitu penelitian hukum yang mengkaji serta menganalisis bekerjanya hukum di dalam masyarakat. ${ }^{4}$ Pendekatan penelitian menggunakan pendekatan yuridis sosiologis, dalam arti pendekatan terhadap hukum sebagai suatu norma dan pendekatan terhadap masyarakat dengan melihat realita di dalam masyarakat. ${ }^{5}$ Dalam hal ini menggambarkan dan menganalisis tentang pelaksanaan pendataan dan penyaluran Dana Bantuan Langsung Tunai Dana Desa Penanggulangan Covid-19 oleh Pemerintah Desa di Kecamatan Depati VII Kabupaten Kerinci serta permasalahanpermasalahannya.

\section{Ruang Lingkup atau Objek Penelitian}

Objek penelitian ini yaitu pelaksanaan pendataan dan penyaluran dana BLT Dana Desa dan permasalahanpermasalahan di Desa dalam Kecamatan Depati VII Kabupaten Kerinci.

\section{Bahan dan Alat Utama}

Karena merupakan penelitian hukum empiris, maka bahan penelitian yang diperlukan adalah data primer dan data sekunder. Data primer yakni data yang diperoleh sumbernya langsung dari lapangan. ${ }^{6}$ Dalam hal ini, data primer berupa data yang terkait dengan pelaksanaan pendataan dan penyaluran Dana BLT Dana Desa yang dilaksanakan pada empat desa yang menjadi objek penelitian di Kecamatan Depati VII Kabupaten Kerinci. Data diperoleh dari responden secara langsung pada keempat yang diteliti. Sedangkan data sekunder lainnya didapat melalui peraturan perundang-

\footnotetext{
${ }^{4}$ Lihat dalam Ishaq, Metode Penelitian Hukum, (Bandung : Alfabeta, 2016), hlm. 71

${ }^{5}$ Lihat Suratman dan Phillip Dillah, Metode Penelitian Hukum, (Bandung : Alfabeta, 2012), hlm. 229 ${ }^{6}$ Ishaq, Op., Cit, hal.7
} 
undangan terkait, buku-buku, jurnal serta referensi terkait lainnya. Untuk mendapatkan data penelitian, alat utamanya yaitu alat tulis guna mencatat informasi atau data yang didapat melalui hasil penelitian.

\section{Tempat/Lokasi Penelitian}

Penelitian ini dilakukan di 4 (empat) Desa yang berada di Kecamatan Depati VII kabupaten Kerinci. Keempat Desa tersebut yaitu Desa Tebat Ijuk, Desa Tebat Ijuk Dili, Desa Sekungkung dan Desa Tambak Tinggi.

\section{Teknik Pengumpulan Data}

Untuk pengumpulan data dilakukan dengan teknik sebagai berikut:

1. Untuk pengumpulan data primer dilakukan dengan cara wawancara dan observasi. Wawancara dilakukan secara langsung dengan responden Kepala Desa/Perangkat Desa pada empat Desa yang diteliti di Kecamatan Depati VII Kabupaten Kerici, kemudian Responden penerima Dana BLT Dana Desa Penanggulangan Covid 19 pada keempat desa tersebut. Sedangkan observasi dilakukan dengan melakukan pengamatan secara langsung terhadap keadaan responden penerima BLT Dana Desa tersebut.

2. Untuk pengumpulan data sekunder dilakukan dengan cara mempelajari peraturan perundang-undangan, hasil penelitian, maupun referensi lain yang terkait dengan masalah penelitian.

\section{Teknik Analisis Data}

Data-data penelitian yang telah dikumpulkan disusun dan disajikan secara sistimatis, selanjutnya dianalisis secara deskriptif kualitatif, yaitu dengan memberikan pemaparan dan menjelaskan secara rinci dan mendalam untuk mengungkap apa yang terdapat dibalik dari peristiwa nyata dengan maksud mencari nilai-nilai yang terkandung di dalamnya. ${ }^{7}$ Pada penelitian ini memaparkan dan menguraikan secara rinci tentang pendataan dan penyaluran dana BLT Dana Desa pada beberapa Desa di Kecamatan Depati VII Kabupaten Kerinci. Setelah itu diambil kesimpulan sesuai dengan permasalaha yang dibahas.

\section{HASIL DAN PEMBAHASAN}

\section{Ketentuan tentang Kriteria Bagi Penerima Dana BLT Dana Desa Penanganan Covid 19}

Sebagaimana dijelaskan sebelumnya bahwa pemberian BLT-Desa merupakan pemberian uang tunai kepada keluarga miskin atau tidak mampu di Desa yang bersumber dari Dana Desa untuk mengurangi dampak ekonomi akibat adanya pandemic Corona Virus Disease 2019 (Covid 19). Berdasarkan PMK Nomor 40 Tahun 2020, Kepala Desa diberi tanggung jawab untuk melakukan pendataan dan penyaluran agar bantuan tersebut tepat sasaran. Untuk itu telah ditetapkan kriteria penerima BLT ini paling sedikit memenuhi kriteria sebagai berikut:

1. keluarga miskin atau tidak mampu yang berdomisili di Desa bersangkutan; dan

2. tidak termasuk penerima PKH, Kartu Sembako, dan Kartu Pra Kerja

Ditegaskan juga dalam Permen Desa PDTT Nomor 6 tahun 2020 tentang Prioritas Penggunaan Dana Desa Tahun 2020, bahwa keluarga miskin yang menerima BLT-Dana Desa merupakan keluarga yang kehilangan mata pencaharian atau pekerjaan, belum terdata menerima Program Keluarga Harapan (PKH), Bantuan Pangan Non Tunai (BPNT), dan kartu pra kerja, serta yang mempunyai anggota keluarga yang rentan sakit menahun/kronis. Di samping itu, persyaratan/kriteria keluarga miskin calon penerima BLT Dana Desa ini juga ditentukan sebagai berikut:

1. luas lantai $<8 \mathrm{~m} 2 /$ orang

2. lantai tanah/bambu/kayu murah

3. dinding bambu/kayu murah/tembok tanpa plester

4. buang air besar tanpa fasilitas/bersama orang lain

5. penerangan tanpa listrik

6. air minum dari sumur/mata air tidak terlindungi/sungai/air hujan

7. bahan bakar kayu bakar/arang/minyak tanah

8. konsumsi daging/susu/ayam hanya $1 \mathrm{kali} / \mathrm{minggu}$

9. satu stel pakaian setahun

10.makan 1-2 kali/hari

11.tidak sanggup berobat ke puskesmas/polikilinik

12.sumber penghasilan KK petani berlahan $/<500 \mathrm{~m} 2$, buruh tani, buruh nelayan, buruh bangunan, buruh perkebunan, pekerja lain berupah $<$ Rp600 ribu/bulan

7 Mukti Fajar dan Yulianto Achmad, Dualisme Penelitian Hukum Normatif dan Empiris, (Yogyakarta : Pustaka Pelajar, 2019), hlm. 283

11 Ridwan HR , Hukum Administrasi Negara, (Jakarta: PT. Raja Grafindo Persada, 2014), hlm.317-318 
M. Muslih dan Herma Yanti, Pendataan dan Penyaluran Bantuan Langsung Tunai Dana Desa Penanggulangan Covid 19 oleh Pemerintah Desa Di Kecamatan Depati VII Kabupaten Kerinci

13.pendidikan KK tidak tamat sekolah/tidak tamat SD/tamat SD

14.tidak memiliki tabungan/barang mudah dijual minimal Rp500 ribu

Dari 14 kriteria tersebut, calon penerima harus memenuhi minimal sembilan (9) kriteria/KK. Berdasarkan kriteria tersebut terlihat bahwa persyaratan untuk penerima BLT Dana Desa sangat ketat. Adapun jumlah bantuan yang diberikan tersebut berdasarkan PMK Nomor 50 Tahun 2020 tentang Pengelolaan Dana Desa, diberikan selama 6 bulan yang mulai disalurkan paling cepat pada bulan April 2020 dengan ketentuan yaitu sebesar Rp600.000,00 untuk bulan pertama sampai bulan ketiga, dan selanjutnya sebesar Rp300.000,00 untuk bulan keempat sampai bulan keenam.

\section{Pelaksanaan Pendataan dan Penyaluran Dana BLT Penanganan Covid 19 oleh Pemerintah Desa di Kecamatan Depati VII Kabupaten Kerici}

Berdasarkan hasil penelitian pada ke empat Desa di Kecamatan Depati VII Kabupaten Kerinci, diketahui bahwa jumlah penerima BLT Dana Desa pada masing-masing Desa tersebut adalah sebagai berikut :

Tabel 1. Jumlah Penerima Dana BLT dana Desa di beberapa Desa pada Kecamatan Depati VII Kabupaten Kerinci.

\begin{tabular}{|c|c|c|c|c|}
\hline No & Nama Desa & Jumlah Kepala Keluarga (KK) & Jumlah Penerima Dana BLT Dana Desa & $\%$ \\
\hline 1. & Desa Tebat Ijuk Dili & $200 \mathrm{KK}$ & 60 & 30 \\
\hline 2. & Desa Tebat Ijuk & $360 \mathrm{KK}$ & 78 & 21,66 \\
\hline 3. & Desa Tambak tinggi & $822 \mathrm{KK}$ & 153 & 18,6 \\
\hline 4. & Desa Sekungkung & $423 \mathrm{KK}$ & 105 & 24,82 \\
\hline
\end{tabular}

Sumber data : hasil penelitian lapangan

Berdasarkan data di atas dilihat bahwa jumlah penerima BLT pada Desa Tebat Ijuk Dili adalah 60 KK dari dari 200 KK yang ada di Desa tersebut. Pada Desa Tebat Ijuk, terdapat 78 KK dari 360 KK yang ada. Kemudian di Desa Tambak Tinggi dengan jumlah KK paling banyak sebesar $822 \mathrm{KK}$, hanya terdapat sebanyak $153 \mathrm{KK}$ penerima BLT dana Desa. Selanjutnya di Desa Sekungkung, terdapat 105 KK dari 423 KK yang ada. Data di atas juga menunjukkan bahwa jumlah penerima BLT Dana Desa di masing-masing Desa tersebut rata-rata hanya sebagian kecil dibandingkan dengan jumlah keseluruhan KK yang ada di masing-masing Desa. Paling menonjol terlihat di Desa Tambak Tinggi yang memiliki jumlah KK paling banyak yaitu $822 \mathrm{KK}$, jumlah penerima BLTnya hanya $153 \mathrm{KK}$.

Terkait dengan kecilnya jumlah penerima dana BLT Dana Desa pada Kecamatan Depati VII Kerinci tersebut, disebabkan karena kesulitan memenuhi kriteria penerima bantuan yang ditentukan Pemerintah. Hal ini terungkap berdasarkan hasil wawancara dengan Chandra Tosa, Sekretaris Desa tambak Tinggi mengungkapkan bahwa :

"Di Desa Tambak Tinggi terdapat 822 KK yang terdata, setelah dilakukan pendataan menyesuaikan dengan kriteria yang ditentukan untuk calon penerima Dana BLT Dana Desa Penanganan Covid-19, saya merasa kesulitan dikarenakan ketentuan mengenai pendapatan calon penerima yang harus kurang dari Rp600.000,- (lima ratus ribu rupiah). Kalau dilihat dari kenyataannya mulai dari pendapatan terkecil yang hanya Rp35.000,- (tiga puluh lima ribu rupiah) perhari saja seorang buruh cuci pakaian memiliki penghasil Rp1.050.000,- (satu juga lima puluh ribu rupiah) perbulannya. Namun setelah hasil Musyawarah yang dilakukan bersama sama dengan Babinsa dan Tokoh Pemuka Masyarakat, disimpulkan tentang jumlah pendapatan terkecil yang dapat dimasukan ke dalam kategori miskin pada Desa Tambak Tinggi. Pada akhirnya kami dapat mendata 153 (seratus lima puluh tiga) Kepala Keluarga yang dapat masuk kriteria calon penerima Dana BLT Dana Desa Penanganan Covid-19. ${ }^{8}$

Informasi tersebut sekaligus menggambarkan bahwa kriteria yang ditetapkan Pemerintah untuk calon penerima dana BLT Dana Desa tidak relevan dengan kondisi di lapangan, sehingga Pemerintah Desa kesulitan untuk memenuhi standar tersebut.

Terkait dengan pelaksanaan pendataan terhadap penerima dana bantuan tersebut, berdasarkan informasi yang dihimpun dari responden Kepala Desa/Sekretaris Desa pada empat Desa yang diteliti, diketahui bahwa proses pendataan dan penyaluran dana BLT Dana Desa di Kecamatan Depati VII Kerinci ini tahapannya dimulai dengan mengadakan rapat/musyawarah yang dihadiri oleh Kepala Desa, anggota DPD, para perangkat Desa, Tokoh masyarakat/tokoh adat dan para kepala dusun untuk membicarakan tentang siapa-siapa yang berhak menerima bantuan. Pendataan terhadap calon penerima pada keempat Desa tersebut dilaksanakan oleh Kepala Dusun di masingmasing desa karena lebih dekat dan lebih mengetahui kondisi masyarakat. Selanjutnya Kepala Dusun menyampaikannya kepada Kepala Desa untuk proses lebih lanjut. 
Adapun kriteria untuk menentukan penerima Dana BLT Dana Desa di masing-masing desa tersebut, dalam hal ini Yulianis Kepala Desa Tebat Ijuk Dili mengungkapkan sebagai berikut :

"Melihat masyarakat yang berhak menerima, mereka yang hanya di rumah dan tidak mempunyai kegiatan yang dapat mendatangkan penghasilan selama pandemi, tidak mendapatkan bantuan lainnya seperti PKH. Yang diprioritaskan adalah Lansia yang tidak menerima pensiunan, menderita penyakit menahun, keluarga yang kepala keluarganyaperempuan/lansia".

Kemudian Zolhadi, Pjs Kepala Desa Sekungkung juga menjelaskan bahwa :

"Proses pendataan dan penyaluran dana BLT Dana Desa ini tahapannya dimulai dengan mengadakan rapat desa, memilah calon penerima agar tidak tumpang tindih dengan penerima PKH dan bantuan lainnya. Orang yang layak adalah orang yang miskin, menderita penyakit menahun, pengangguran, orang yang kena PHK akibat dampak covid".

Sementara di Desa Tambak Tinggi yang jumlah KKnya paling banyak, namun kesulitan memenuhi kriteria yang ditetapkan pemerintah, setelah dilakukan rapat desa, maka kriteria calon penerimanya sebagaimana disampaikan oleh Chandra Tosa, Sekretaris Desa Tambak Tinggi ditentukan sebagai berikut :

1. Keluarga Miskin (Prioritas Kepala Keluarga Perempuan/Lansia)

2. Memiliki Penyakit Menahun/Kronis

3. Tidak menerima bantuan lain

4. Bukan Pensiunan PNS/BUMN

5. Memiliki pendapatan kurang dari Rp.800.000,- perbulan (delapan ratus ribu rupiah).

6. Tidak memiliki kegiatan yang dapat menafkahi keluarga selama masa pandemi.

Berdasarkan informasi yang disampaikan responden pada keempat Desa di atas, menunjukkan bahwa pada prinsipnya responden memiliki pandangan yang sama tentang kriteria bagi penerima dana BLT Dana Desa tersebut, artinya para pejabat desa tersebut telah memahami kriteria yang telah ditetapkan pemerintah, bahwa penerima BLT Dana Desa ini diutamakan adalah masyarakat miskin dan tidak menerima bantuan lainnya dari pemerintah, serta masyarakat yang menderita penyakit menahun, tidak mempunyai pekerjaan/penghasilan, keluarga dengan kepala keluarga perempuan serta tidak menerima pension.

Adapun penyaluran Dana BLT Dana Desa pada keempat Desa tersebut, berdasarkan informasi yang disampaikan oleh Responden para Pejabat Desa dari keempat desa tersebut, mengungkapkan bahwa Dana BLT-Dana Desa Penanganan Covid-19 diterima masyarakat secara bertahap. Tahap pertama diberikan tiga kali selama terdata sebagai penerima dengan jumlah sebesar Rp. 600.000,- (enam ratus ribu rupiah). Pada tahap selanjutnya ada penambahan jumlah penerima tapi jumlah nominal rupiahnya berkurang menjadi sebesar Rp. 300.000 (Tiga Ratus Ribu Rupiah) per KK.

Penyaluran BLT Dana Desa dilakukan di kantor Desa. Dalam hal ini kepada masyarakat disampaikan pemberitahuan sehari sebelumnya, kemudian masyarakat datang ke kantor desa pada hari yang ditentukan dengan mengikuti protokol kesehatan yaitu mencuci tangan dan pake masker.

\section{Permasalahan-Permasalahan Dalam Pendataan dan Penyaluran Dana BLT Penanganan Covid 19 oleh Pemerintah Desa di Kecamatan Depati VII Kabupaten Kerici}

Meskipun semua Kepala Desa serta semua perangkat desa telah memahami kriteria-kriteria masyarakat penerima BLT Dana Desa Penanggulangan Covid 19 yang telah ditentukan, namun dalam pelaksanaannya ditemui berbagai permasalahan terkait dengan penyaluran dana tersebut. Adapun permasalahan tersebut adalah sebagai berikut:

\section{Pemberian BLT Dana Desa yang Menyalahi Ketentuan}

Adanya penyaluran dana yang menyalahi ketentuan ini terjadi di Desa Tebat Ijuk Dili, karena Kepala Desa memasukkan perangkat desa sebagai penerima bantuan tersebut. Informasi ini telah berkembang menjadi sorotan publik karena sudah dimuat di media local dan media online. Berdasarkan informasi yang dimuat dalam media Gegeronline tanggal 21 Maret 2021, memuat sebanyak 13 nama penerima disertai dengan profesi masing-masing yang dianggap tidak layak menerima dana BLT Dana Desa tersebut, yang terdiri dari 2 orang pedagang, 1 orang laya (mampu), 1 orang istri BPD, 6 orang yang masing-masingnya berstatus sebagai istri dari 6 orang staf desa, Sekretaris 
Desa, Suami bendahara desa dan satu orang pensiunan PTPN. ${ }^{9}$ Sebelumnya informasi ini juga sudah dipublikasikan melalui media Jendela Publik tanggal 20 Desember 2020. Media ini juga telah berusaha mengkonfirmasi Kepala Desa (Yulianus) di kediamannya. Namun terkesan mengelak dan selalu tidak ada di rumah, saat diminta keterangan lebih lanjut terkait akan benar tidaknya informasi tersebut. Sampai berita ini dipublis Kepala Desa Tebat Ijuk Dili tidak bisa dihubungi. ${ }^{10}$

Sehubungan dengan penyaluran dana yang tidak tepat tersebut dapat dikatakan bahwa tindakan Kepala Desa tersebut telah menyalahi asas tidak menyalahgunakan kewenangan. Dalam hal ini Kepala Desa dianggap telah menggunakan kewenangannya untuk kepentingan kepentingan yang lain dan tidak sesuai dengan tujuan pemberian kewenangan tersebut. Apalagi tindakan Kepala Desa yang memutuskan memberikan bantuan kepada Perangkat Desa yang tidak masuk dalam kriteria penerima bantuan. Demikian juga sikap Kepala Desa yang tidak memberikan penjelasan atas korfirmasi informasi yang disampaikan kepadanya, merupakan sikap yang menyalahi asas keterbukaan, dimana seharusnya yang bersangkutan melayani masyarakat untuk memperoleh informasi yang benar dalam penyelenggaraan pemerintahan. Namun, pada kenyataannya Kepala Desa Tebat Ijuk Dili tidak memberikan akses untuk memperoleh informasi mengenai data terkait dengan penyaluran dana BLT Dana Desa tersebut.

Adanya penerima yang tidak sesuai ketentuan ini juga terungkap berdasarkan informasi yang diperoleh dari salah seorang responden penerima dana BLT, yaitu Ilhami yang merupakan penerima pensiunan dari BUMN yang mengungkapkan bahwa dirinya sebelumnya termasuk didalam daftar penerima dana BLT-Dana Desa Penanganan Covid-19, dan sempat menerima Dana Bantuan tersebut selama 3 (tiga) bulan. Yang bersangkutan diberitahukan oleh Pihak Pemerintah Desa Tebat Ijuk Dili bahwa dirinya telah terdaftar sebagai penerima Dana BLT-Dana Desa Penanganan Covid-19 dan mengaku sama sekali tidak mengetahui jika dirinya tidak sepatutnya menerima Dana BLT, karena suaminya adalah Pensiunan dari perusahaan BUMN dan menerima Dana Pensiun.

Selain di Desa Tebat Ijuk Dili, adanya penerima bantuan yang tidak sesuai ketentuan ini juga diketahui berdasarkan wawancara dengan responden penerima dana BLT dari Desa Sekungkung, yaitu Yusnaini. Responden juga mengaku sama sekali tidak mengetahui tentang kriteria penerima Dana BLT Dana Desa Penanganan Covid-19 ini, karena dirinya tiba-tiba diberitahu oleh pihak Pemerintah Desa Sekungkung bahwa telah terdaftar sebagai penerima Dana BLT-Dana Desa. Responden mengaku baru mengatahui informasi tersebut dari peneliti dan menyatakan akan mengajukan pengunduran diri dari daftar penerima Dana BLT Dana Desa tersebut karena responden merupakan pensiunan PNS yang menerima Dana Pensiun setiap bulannya.

Hal di atas memperlihatkan bahwa Pemerintah Desa tidak memenuhi asas kecermatan, dimana seharusnya sebelum mengambil keputusan atau tindakan, penyelenggara pemerintahan seharusnya mempersiapkannya secermat mungkin, sehingga dapat mencegah kerugian bagi pihak lainnya. Dalam hal ini bisa jadi masyarakat yang berhak menerima bantuan, tetapi terlewatkan. Sementara yang tidak berhak menerima bantuan, malah mendapatkan bantuan. Dalam hal ini Marbun yang dikutip Oleh Gunawan, mengungkapkan bahwa aparatur negara yang meliputi presiden hingga perangkat desa memegang peranan penting dan bertanggung jawab dengan kehidupan masyarakat mulai dari aturan yang diterapkan aparatur negara harus memantau efektif atau tidaknya penerapan aturan yang dijalankan atau diterapkan di kehidupan masyarakat. Maka dari itu keberadaan AAUPB sangat membantu kehidupan bermasyarakat guna mencari keadilan jika dimana pejabat membuat undang-undang yang dianggap merugikan masyarakat dengan alasan kepentingan penyelenggaraan negara. ${ }^{11}$

Oleh karena itu, seyogyanya pemerintah desa dalam hal pendataan dan penyaluran BLT-Dana Desa ini untuk menjalankan prinsip-prinsip AAUPB tersebut di atas. Keberadaan AAUPB dapat melindungi masyarakat dari keputusan pemerintah desa yang menyimpang, dan dapat pula menjadi dasar gugatan bagi masyarakat untuk mendapatkan keadilan.

Adanya pelanggaran-pelanggaran yang dikemukakan di atas menunjukkan bahwa masih terdapat penyimpangan pada pendataan dan penyaluran BLT-Dana Desa yang seharusnya bisa di atasi jika pemerintah desa menerapkan prinsip AAUPB dengan lebih teliti dan seksama dan berorientasi pada kepentingan bersama.

\section{Tumpang Tindih Penerima bantuan}

Adanya tumpang tindih dalam pemberian bantuan ini diungkapkan oleh Chandra Tosa, Sekretaris Desa Tambak Tinggi bahwa Di Desa tambak Tinggi terdapat 3 (tiga) orang yang seharusnya tidak mendapat bantuan BLT Dana Desa, karena sudah mendapatkan bantuan lain. Dari ketiga orang tersebut ada yang mendapatkan bantuan PKH, ada yang mendapatkan kartu prakerja dan ada juga yang mendapatkan pensiun, tetapi tetap mendapatkannya. hal ini disebabkan kelalaian dalam proses pendataan calon penerima.

\footnotetext{
${ }^{9}$ Gegeronline, Penyaluran Dana BLT Desa Tebat Ijuk Dili Tak Tepat Sasaran,

${ }^{10}$ Jendela Publik, hhtp//Jendela Publik.com diakses 20 Desember 2020

11 A. Arthanaya Gunawan, "Fungsi Asas Asas Umum Pemerintahan yang baik dalam Menyelesaikan sengketa hukum Acara tata Negara", Jurnal Analogi Hukum, Volum 1 No 1, 2019, hal. 31.
} 
Adanya tumpang tindih penerima bantuan ini tidak relevan dengan asas kepastian hukum yang mengutamakan landasan ketentuan peraturan perundang-undangan, kepatutan dan keadilan dalam setiap kebijakan. Begitu juga Dengan adanya bantuan ganda ini tentunya menimbulkan ketidakadilan dengan yang lainnya. Adanya penerima ganda ini sekaligus juga tidak relevan dengan asas kecermatan dalam melakukan tindakan pendataan.

\section{Masalah Ketidaksesuaian Data}

Masalah lain yang menjadi perhatian adalah pernyataan Sekretaris Tambak Tinggi yang menyebutkan bahwa Desa tambak Tinggi masih menggunalan Data 2017. Yang menjadi permasalan adalah mengenai data pemerintahan desa yang disebutkan telah menggunakan data 2017, sedangkan Bantuan Langsung Tuna Dana Desa (BLT-Dana Desa) dimulai dari tahun 2020. Dalam jangka waktu 2017-2020 tentu saja terjadi banyak perubahan data yang mengakibatkan kemungkinan bantuan tidak tepat sasaran karena ketidak sesuaian data menjadi sangat besar.

Hal ini tentunya tidak relevan dengan asas kemanfaatan dimana salah satu poin dari asas kemanfaatan adalah keseimbangan antara kepentingan individu yang satu dengan individu yang lain. Dengan tidak melakukan perbaharuan data, pemerintahan desa telah melakukan ketidak adilan dimana bisa saja ada individu yang tidak lagi membutuhkan bantuan tapi mendapatkannya, sementara itu individu yang tidak/belum termasuk dalam kriteria penerima bantuan tapi memerlukannya saat ini malah tidak mendapatkannya dikarenakan keterbatasan kuota.

Kasus ini juga tidak sesuai dengan asas kecermatan, dimana sebuah tindakan yang bersangkutan seharusnya dipersiapkan dengan cermat sebelum Keputusan dan/atau Tindakan tersebut ditetapkan dan/atau dilakukan. Pemerintahan Desa tidak bisa begitu saja menggunakan data lama, tanpa mempertimbangkan perubahan data yang mungkin terjadi dalam rentang waktu 2017-2020.

Selanjutnya pernyataan di atas juga tidak sesuai dengan asas keterbukaan, jika disandingkan dengan pernyataan Sekretaris Desa Tambak Tinggi yang menyatakan bahwa untuk prosesnya telah sesuai dengan ketentuan yang berlaku atau sesuai dengan kriterianya.

Disebutkan bahwa asas keterbukaan adalah asas yang melayani masyarakat untuk mendapatkan akses dan memperoleh informasi yang benar, jujur, dan tidak diskriminatif dalam penyelenggaraan pemerintahan dengan tetap memperhatikan perlindungan atas hak asasi pribadi, golongan, dan rahasia Negara.

Kedua pernyataan dari Sekretaris Desa tambak tinggi menyebutkan hal yang sangat kontras. Informan menyebutkan 2 hal yang berbeda, tentang data yang telah sesuai kriteria. Namun, pada kenyataannya masih menggunakan data lama. Lebih lanjut, hal ini juga merupakan bentuk ketidak terbukaan pemerintahan desa kepada masyarakat dimana masyarakat tidak mendapatkan akses dan memperoleh informasi yang benar dan jujur.

Fenomana ketidak sesuaian antara pelaksanaan program dan aturan yang berlaku sebagaimana diuraikan di atas dapat juga difahami dari sudut pandang yang lain, Sebagai Negara hukum maka apa yang dilakukan oleh beberapa pemerintahan desa di kecamatan Depati VII Kabupaten Kerinci dalam rangka mendata dan mendistribusi BLT Dana Desa tersebut dapat dimaknai sebagai kegiatan pelaksaan hukum atau dengan kata lain sebagai bekerjanya hukum di dalam masyrakat. Menurut Satjipto Rahardjo ${ }^{12}$ dalam ajaran "hukum sebagai suatu proses" bahwa pelaksanaan hukum dalam masyarakat memerlukan berbagai persiapan dan daya dukung yang memadahi, agar tujuan hukum tersebut dapat direalisasikan dengan baik di lapangan. Dalam konteks penyaluran BLT Dana Desa di atas Nampak bahwa daya dukung berupa keterbatasan data tentang kondisi keluarga tidak memadahi, apalagi Permen Desa PDTT menetapkan bahwa persyaratan keluarga penerima BLT DD minimal memenuhi 9 kriteria dari 14 kriteria yang ditetapkan oleh pemerintah pusat. Penyusunana kriteria seperti dimaksud di atas tentu memerlukan waktu, tenaga dan kecermatan yang tinggi untuk identifikasi dan verifikasi baik administrasi maupun faktual.

Tantangan dan kesulitan lain dalam mencegah terjadinya duplikasi bantuan pemerintah, mengingat pemerintah mengaluarkan macam-macam paket bantuan kepada warga masyarakat/ warga desa. Oleh karena itu wajar jika terdapat masyarakat/ keluarga yang memperoleh lebih dari satu macan bantuan. Hal ini juga diakibatkan keterbatasan data keadaan dan kondisi sosial ekonomi kelurga yang ada di desa. Apalagi yang namanya keadaan siosial ekonomi keluarga tidak statis, namun berfifat dinamis, maka abditing data secara periodic sangat dipelukan.

Faktor daya dukung yang tidak kalah penting adanya sikap batin/ attitude dan perilaku warga masyarakat sadar jika dirinya merasa mampu dan tidak perlu dibantu, sebaiknya tidak menerimanya atau bahkan menegmbalikan kepada desa agar dapat disalurkan kepada warga yang memang berhak dan perlu dibantu dengan BLT Dana Desa tersebut.

Terkait dengan masalah ketidak-tepatan sasaran pemberian BLT Dana Desa di suatu desa, atau bahkan diberikan kepada sebagian keluarga aparatur pemerintahan desa di desa yang lainnya, maka kinerja yang demikian ini jika dilihat sebagai suatu kinerja manajemen lembaga hukum (pemerintah desa) merupakan hal yang wajar dan

${ }^{12}$ Satjipto Rahardjo, Hukum dan Masyarakat, Penerbit Angkasa Bandung, Cetakan ke 3 Tahun 1980 hal 62. 
biasa terjadi. Sebab menurut Chambliss dan Seidman sebagaimana dikutip Satjipto Rahardjo ${ }^{13}$, bahwa secara alamiah suatu institusi hukum (dalam hal ini desa yang jadi sampel penelitian) akan cenderung membuat kebijakankebijakan guna mencapai tujuan hukum jika tujuan hukum tersebut tidak dapat diwujudkan menurut peraturan yang berlaku. Dalam perilaku manajemen (hukum) telah terbentuk budaya "maximizing reward and minimizing strains on the organization", bahwa setiap organisasi akan cenderung mengganti tujuan dan kaedah organisasi dengan kebijakan kebijakan yang menguntungkan dan menekan hambatan terhadap organisasi tersebut.

Dalam konteks pemberian BLT Dana Desa ini kemungkinan memang ada motif keuntungan pribadi/ keluarga, akan tetapi ada juga kemungkinan tidak mencari keuntungan finansial, tetapi tindakan memberikan BLT Dana Desa kepada sebagian kelurga yang telah menerima bantuan/ paket lain dari pemerintah, ataupun BLT Dana Desa yang diberikan kepada sebagian keluarga aparatur desa lebih disebabkan untuk memudahkan kinerja aparatur agar dana yang dibebankan kepada desanya cepat tersalurkan sesuai dengan jumlah dan batasan waktu. Masalah ini dapat dikaitkan dengan adanya aturan tentang konsekwensi jika anggaran desa tidak tersalurkan sesuai dengan yang dianggarkan, maka anggaran tahun berikutnya akan dikurangi. Hal ini bisa juga menjadi pemicu dibawah sadar sehingga tindakan penyaluran BLT Dana Desa tersebut majadi kurang kehati-hatian (prudensialitas), yang menyebabkan terlanggarnya azas umum pemerintahan yang baik.

Analisis ini tidak bermaksud membela dan membenarkan kesalahan-kesalahan dalam distribusi BLT Dana Desa di Kecamatan Batin VII Kabupten Kerinci, melainkan berusaha mendiskripsikan akar permasalahan yang berpotensi menyebabkan berbagai kesalahan penyaluran BLT Dana Desa diatas terjadi.

\section{SIMPULAN}

Berdasarkan uraian, maka dapat disimpulkan bahwa Pendataan dan penyaluran dana BLT Dana Desa oleh Pemerintah Desa di Kecamatan Depati VII Kabupaten Kerinci belum sepenuhnya sesuai dengan ketentuan peraturan perundang-undangan yang menjadi landasan dalam pemberian bantuan tersebut. Hal ini terlihat dari beberapa permasalahan berupa adanya penyaluran dana bantuan yang diberikan kepada pihak-pihak yang tidak layak menerima bantuan karena tidak sesuai dengan kriteria yang telah ditetapkan, adanya masyarakat yang meneriman bantuan ganda (tumpang tindih) dengan bantuan pemerintah lainnya, serta adanya ketidaksesuaian data yang dijadikan dalam pemberian bantuan. Permasalahan-permasalahan tersebut sekaligus menunjukkan adanya ketidak sesuaian antara keputusan/tindakan pemberian bantuan dengan prinsip-prinsip atau asas-asas umum pemerintahan yang baik yang seharusnya menjadi pegangan bagi pemerintahan desa dalam pemberian dana BLT Dana Desa yang sejatinya diperuntukkan bagi masyarakat miskin yang tidak mampu secara finansial akibat terdampak Pandemi Covid 19.

\section{DAFTAR PUSTAKA}

\section{Buku}

Fajar ND Mukti dan Ahmad Yulianto, Dualisme Penelitian Hukum Normatif \& Empiris, Jakarta: Pustaka Pelajar, 2019

Hamidi Jazim, Penerapan Asas-Asas Umum Pemerintahan Yang Layak (AAUPL) di Lingkungan Peradilan

Administrasi Indonesia, Bandung : Citra Aditya Bakti, Bandung, 1999

Ishaq, Metode Penelitian Hukum, Bandung: Alfabeta, 2017

Ridwan HR, Hukum Administrasi Negara, Jakarta: PT. Raja Grafindo, 2007

Satjipto Rahardjo, Hukum dan Masyarakat, Angkasa, Bandung 1980

--------------, Masalah Penegakan Hukum, suatu Tinjauan Sosiologis, BPHN-Sinar Baru, Bandung, tanpa tahun

Suratman dan Philips Dillah, Metode Penelitian Hukum, Alfabeta.Malang, 2014

\section{Peraturan Perundang-Undangan}

Undang-Undang Dasar Negara Republik Indonesia Tahun 1945

Undang-undang Nomor 30 tahun 2014 tentang Administrasi Pemerintahan

Pemerintah Desa Peraturan Mentri Desa Nomor 6 Tahun 2020 tentang Prioritas Penggunaan Dana Desa

Peraturan Mentri Dalam Negeri Nomor 3 Tahun 2020 tentang Penanggulangan COVID-19 di Desa Melalui APBDes

Peraturan Menteri Keuangan Nomor 40 Tahun 2020 tentang Pengelolaan Dana Desa

\section{Jurnal}

A. Arthanaya Gunawan, "Fungsi Asas Asas Umum Pemerintahan yang baik dalam Menyelesaikan sengketa hukum Acara tata Negara", Jurnal Analogi Hukum, Volum 1 No 1, 2019.

${ }^{13}$ Satjipto Rahardjo, Masalah Penegakan Hukum, Suatu Tinjauan Sosiologis, BPHN, dan Sinar Baru Bandung, tanpa Tahun, hal 22. 
M. Muslih dan Herma Yanti, Pendataan dan Penyaluran Bantuan Langsung Tunai Dana Desa Penanggulangan Covid 19 oleh Pemerintah Desa Di Kecamatan Depati VII Kabupaten Kerinci

\section{Website}

Jendela Publik, hhtp//Jendela Publik.com

Bappenas.go.id.

https:gegeronline.co.id 